\title{
Ammonium Production in Submerged Soils and Sediments: The Role of Reducible Iron
}

\author{
K. L. Sahrawat* \\ International Crops Research Institute for the Semi-Arid Tropics \\ (ICRISAT), Patancheru, Andhra Pradesh, India
}

\begin{abstract}
Submerged soils differ considerably from their arable counterparts. Lack of oxygen and the reduced state of submerged soils cause this. Submerging a soil under water triggers a series of physical, chemical and biological changes that greatly affect the dynamics of soil fertility and its use for growing crops such as wetland rice. Due to lack of oxygen, the nitrogen $(\mathrm{N})$ mineralization process in submerged soils stops at ammonium production and nitrification is at low ebb. Most rice soils, especially those in the tropics are rich in iron (Fe). Redox cycling of Fe exerts a wide-ranging influence on the biogeochemistry of submerged rice soils and aquatic sediments where $\mathrm{Fe}$ is abundant. This article critically assesses the literature on the role of reducible $\mathrm{Fe}$, which participates in redox reactions in submerged
\end{abstract}

*Correspondence: K. L. Sahrawat, International Crops Research Institute for the Semi-Arid Tropics (ICRISAT), Patancheru 502 324, Andhra Pradesh, India; Fax: +91 40 23241239/23296182; E-mail: klsahrawat@yahoo.com.

399

DOI: $10.1081 / C S S-120029721$

Copyright $\odot 2004$ by Marcel Dekker, Inc.

0010-3624 (Print); 1532-2416 (Online) www.dekker.com 
soils, on ammonium production or $\mathrm{N}$ mineralization in submerged soils and sediments. The reduction of $\mathrm{Fe}$ and organic matter oxidation in submerged soils and wetland sediments are interdependent. Results with freshwater sediments have indicated a direct correlation between $\mathrm{Fe}$ (III) oxide reduction rate constants and initial rates of organic $\mathrm{C}$ mineralization. The role of reducible $\mathrm{Fe}$ on $\mathrm{N}$ mineralization or ammonium production is not clearly understood. However, recent research with diverse West African rice soils showed that ammonium production in submerged soils is highly significantly correlated to reducible Fe. The results demonstrated that organic matter and reducible $\mathrm{Fe}$ control ammonium production in submerged soils. There is a need for future research to further elucidate the role and involvement of reducible $\mathrm{Fe}$ on $\mathrm{N}$ mineralization or ammonium production in submerged soils and sediments.

Key Words: Ammonium production; Iron redox couple; $\mathrm{N}$ nutrition of plants; Wetland soils and sediments; Role of electron acceptors; Organic matter; Redox potential.

\section{INTRODUCTION}

Globally, approximately 130 million ha land, constituting about $10 \%$ of the arable land, is temporarily flooded or submerged for wetland rice production. ${ }^{[1]}$ Flooding of soil under water greatly affects soil physical, chemical and biological properties through the well-known process of soil reduction caused by redox processes. The chemistry of submerged soils has been the subject of several reviews, covering various redox processes and nutrient transformations in these soils. ${ }^{[2-6]}$ The soil reduction-mediated physical, chemical and biological processes profoundly influence the quality of soil as a medium for the growth of crops such as wetland rice. ${ }^{[2,3,5-7]}$

Iron $(\mathrm{Fe})$ is present in large amounts especially in tropical soils. ${ }^{[8]}$ The Fe redox chemistry plays an important role in influencing the dynamics of soil fertility through its role on soil reduction and release of nutrient elements in solution of submerged rice soils. ${ }^{[5,9]}$

Ammonium production is the key process for nitrogen $(\mathrm{N})$ nutrition of wetland rice. The soil $\mathrm{N}$ supply plays a dominant role in the $\mathrm{N}$ nutrition of wetland rice. Over $50 \%$ of the $\mathrm{N}$ taken up by the rice crop even in $\mathrm{N}$ fertilized rice paddies come from the soil pool. ${ }^{[10]}$ The role of organic matter in controlling ammonium production or $\mathrm{N}$ mineralization in submerged soils is well known. ${ }^{[10-14]}$ 
The role of $\mathrm{Fe}$ redox chemistry on $\mathrm{N}$ mineralization or ammonium production in wetland soils is not well understood. However, it is known that the most important geochemical change that takes place in many submerged soils and aquatic sediments is the reduction of $\mathrm{Fe}(\mathrm{III})$ to $\mathrm{Fe}(\mathrm{II})$ or Fe redox chemistry. ${ }^{[2,3,9]}$ The reduction of $\mathrm{Fe}(\mathrm{III})$ to $\mathrm{Fe}(\mathrm{II})$ greatly influences Fe and manganese $(\mathrm{Mn})$ geochemistry and can have profound influence on a range of other important soil properties and fertility status of wetlands as a medium for plant growth and agricultural production. . $^{[2,3,6,15,16]}$

Earlier reviews on the chemistry of submerged soils concentrated on iron redox reactions and its influence on chemical and electrochemical changes and exchange equilibria, soil properties and the dynamics of plant nutrients. This article focuses on the role of free or reducible iron, which participates in redox reactions in anaerobic or submerged environments, on organic matter mineralization and ammonium production in wetland soils and sediments. Nitrogen supply under submerged conditions, which depends on organic matter mineralization and ammonium production, is the key process for $\mathrm{N}$ nutrition of wetland rice and in regulating the primary productivity of wetlands.

This article is an attempt to critically review the role reducible $\mathrm{Fe}$ plays in ammonium production and $\mathrm{N}$ mineralization in wetland soils and sediments and suggests future areas of research. It is hoped that this review will stimulate further research in this important area because $\mathrm{N}$ supply (ammonium production) and cycling have a major influence on natural and agricultural wetlands' role in controlling productivity, regulating environmental quality, and determining the sustainability of wetland ecosystems.

\section{REDOX COUPLES AND ELECTRON ACCEPTORS IN WETLANDS}

Principal redox couples in sequence in submerged soils are: $\mathrm{O}_{2} / \mathrm{H}_{2} \mathrm{O}$, $\mathrm{NO}_{3}^{-} / \mathrm{N}_{2}, \mathrm{Mn}(\mathrm{IV}, \mathrm{III}) / \mathrm{Mn}(\mathrm{II}), \mathrm{Fe}(\mathrm{III}) / \mathrm{Fe}(\mathrm{II}), \mathrm{SO}_{4}^{2-} / \mathrm{H}_{2} \mathrm{~S}$, and $\mathrm{CO}_{2} / \mathrm{CH}_{4}$.

The main electron-acceptors in submerged soils include dissolved $\mathrm{O}_{2}, \mathrm{NO}_{3}^{-}, \mathrm{Fe}(\mathrm{III}), \mathrm{SO}_{4}^{2-}$, and $\mathrm{CO}_{2}$. The final products of reduction in submerged soils are $\mathrm{Fe}(\mathrm{II}), \mathrm{H}_{2} \mathrm{~S}$, and $\mathrm{CH}_{4}$, although intermediate products such as dissolved $\mathrm{H}_{2}$ and $\mathrm{H}_{2} \mathrm{~S}$ are also found in submerged soils and sediments. ${ }^{[17]}$

As mentioned in the introduction, the redox reactions influence soil properties and fertility in submerged soils and sediments which affect 
their primary productivity and environmental quality. ${ }^{[2,16,18,19]}$ It is known that when soil is submerged into water, oxygen in the system is rapidly consumed during aerobic microbial respiration. This is followed by successive use of $\mathrm{NO}_{3}^{-}, \mathrm{Mn}(\mathrm{IV}), \mathrm{Fe}(\mathrm{III})$, and $\mathrm{SO}_{4}^{2-}$ as electron acceptors in anaerobic microbial respiration. ${ }^{[3]}$

Also, in the absence of oxygen, facultative and obligate anaerobes use the dissimilation products of carbohydrates and proteins as electron acceptors in their respiration. ${ }^{[3]}$ In most rice soils, Fe is the main electron acceptor. Iron occurs as $\mathrm{Fe}$ (III) oxides and oxyhydroxides, and in the structure of clay minerals. ${ }^{[20]}$

In a study of the long-term effects of intermittent flooding of a Vertisol, Favre et al. ${ }^{[21]}$ showed that cation exchange capacity (CEC) of the soil in the reduced state following flooding increased to twice that of its oxidized, unflooded state. The increase in CEC was caused by the increase in structural $\mathrm{Fe}(\mathrm{II})$ upon reduction and the removal of $\mathrm{Fe}$ oxyhydroxide coatings by reductive dissolution. Several authors have reported on the role of $\mathrm{Fe}$ on soil properties including CEC. ${ }^{[22-25]}$ It has been suggested that the changes in CEC and related redox reactions may be important in substantially modifying proton, anion, and cation balances in intermittently flooded soils. ${ }^{[21]}$

Soil reduction in submerged soils and sediments is measured by redox potential (Eh) and expressed in $\mathrm{mV}$. The measured Eh can be explained by the concentration of some redox systems. Dissolved $\mathrm{O}_{2}$, $\mathrm{NO}_{3}^{-}$and $\mathrm{SO}_{4}^{2-}$ are relatively electrode-insensitive and others, especially $\mathrm{Fe}(\mathrm{III})$ play important role in the soil reduction, measured by Eh. ${ }^{[17,26,27]}$ In a field study, it was demonstrated that measured Eh showed a higher correlation to redox species $\mathrm{Mn}(\mathrm{II})\left(r^{2}=0.76\right), \mathrm{Fe}(\mathrm{II})\left(r^{2}=0.73\right)$, and methane $\left(r^{2}=0.76\right)$ than to dissolved oxygen, nitrate and sulfate-S. ${ }^{[17]}$

The data on the range of redox potentials (Eh) encountered in soils and sediments ranging from well drained to submerged or flooded conditions are summarized in Table 1. The data can serve as a

Table 1. The range of redox potentials (Eh) encountered in well-drained and submerged soils and sediments. ${ }^{[9]}$

\begin{tabular}{lc}
\hline Soil water condition & Redox potential $(\mathrm{mV})$ \\
\hline Well-drained (aerated) & +700 to +800 \\
Moderately reduced & +400 to +200 \\
Reduced & +100 to -100 \\
Highly reduced & -100 to -300 \\
\hline
\end{tabular}


Table 2. Approximate redox potentials at which the main oxidized components in submerged soils and sediments become unstable..$^{[9,28]}$

\begin{tabular}{lc}
\hline Reaction & Redox potential $(\mathrm{mV})$ \\
\hline $\mathrm{O}_{2}-\mathrm{H}_{2} \mathrm{O}$ & +380 to +320 \\
$\mathrm{NO}_{3}-\mathrm{N}_{2}, \mathrm{Mn}^{4+}-\mathrm{Mn}^{2+}$ & +280 to +220 \\
$\mathrm{Fe}^{3-}-\mathrm{Fe}^{2-}$ & +180 to +150 \\
$\mathrm{SO}_{4}^{2-}-\mathrm{S}^{2-}$ & -120 to -180 \\
$\mathrm{CO}_{2}-\mathrm{CH}_{4}$ & -200 to -280 \\
\hline
\end{tabular}

guideline for classifying soil reduction under diverse soil moisture regime. ${ }^{[9]}$ The approximate Eh values at which the main oxidized components in submerged soils become unstable are shown in Table 2. It is indicated that $\mathrm{Fe}(\mathrm{III})$ is reduced to $\mathrm{Fe}(\mathrm{II})$ at Eh value ranging from 150 to $180 \mathrm{mV}$.

The reduction of $\mathrm{Fe}(\mathrm{III})$ oxides to $\mathrm{Fe}(\mathrm{II})$ can be represented by the following equation, in which $\mathrm{Fe}(\mathrm{III})$ oxides serve as the source of reducible Fe and organic matter $\left(\mathrm{CH}_{2} \mathrm{O}\right)$ serve as the electron donor:

$$
\mathrm{Fe}_{2} \mathrm{O}_{3}+1 / 2 \mathrm{CH}_{2} \mathrm{O}+4 \mathrm{H}^{+}=2 \mathrm{Fe}^{2+}+5 / 2 \mathrm{H}_{2} \mathrm{O}+1 / 2 \mathrm{CO}_{2}
$$

The reduction rate of $\mathrm{Fe}$ is affected by surface chemical reactions and is directly related to the concentration of organic reductant. ${ }^{[29]}$ For example, Gao et al. ${ }^{[17]}$ observed that in submerged paddy field the reduction rates of $\mathrm{Fe}(\mathrm{III})$ to $\mathrm{Fe}(\mathrm{II})$ were faster in straw-incorporated plots as higher soluble, reduced $\mathrm{Fe}(\mathrm{II})$ was detected. Precipitation reaction tends to increase $\mathrm{Fe}(\mathrm{III}) / \mathrm{Fe}$ (II) and derives the reduction $\left(\mathrm{Fe}^{3+}=\mathrm{Fe}^{2+}+\mathrm{H}^{+}\right)$reaction forward. Moreover, application of organic matter has an inhibitory effect on the crystallization of amorphous ferric hydroxides and keeps $\mathrm{Fe}$ in the amorphous and relatively reducible form. ${ }^{[30]}$

Narteh and Sahrawat ${ }^{[6]}$ showed that at 4 weeks after flooding of West African soils, the soil solution Eh can be predicted from the concentration of $\mathrm{Fe}(\mathrm{II})$ in soil solution and soil solution $\mathrm{pH}$ :

$$
\mathrm{Eh}=409-4.09 \log \mathrm{Fe}(\mathrm{II})-59 \mathrm{pH} ; \quad R^{2}=0.99
$$

Furthermore, the changes in soil solution $\mathrm{pH}$ corresponded to changes in soil solution Eh. The stability in Eh-pH relationship was 
recorded at the 4 week after flooding and the relationship was described by the following equation: ${ }^{[6]}$

$$
\Delta \mathrm{Eh}=-16-48 \Delta \mathrm{pH} ; \quad R^{2}=0.84
$$

\section{IRON REDOX AND CARBON METABOLISM}

Geological evidence suggests that $\mathrm{Fe}(\mathrm{III})$ reduction has been an important process for organic matter oxidation since early in the Earth's biotic history. The strong correlation in the occurrence of isotopically light carbonates and magnetite in the pre-Cambrian banded $\mathrm{Fe}$ formations indicates that organic matter oxidation was coupled to $\mathrm{Fe}(\mathrm{III})$ reduction in this environment (for review, see Lovley ${ }^{[16]}$ ). It has been suggested that $\mathrm{Fe}$ may have been central to the overall carbon (C) flow in these pre-Cambrian environments because Fe(II) may have also served as the electron donor for photosynthesis. ${ }^{[31]}$ According to this model, the organic matter and $\mathrm{Fe}$ (III) that were produced as the result of photosynthesis in the water column would then settle out where dissimilatory $\mathrm{Fe}(\mathrm{III})$-reducing microorganisms could oxidize the organic matter with the reduction of $\mathrm{Fe}(\mathrm{III})$. This results in the production of magnetite as well as in the regeneration of dissolved Fe(II) for further photosynthesis.

A number of studies in freshwater and marine sediments indicate that dissimilatory microbial reduction of $\mathrm{Fe}(\mathrm{III})$ oxides contributes substantially to $\mathrm{C}$ metabolism. ${ }^{[32,33]}$ It has been suggested that microbial $\mathrm{Fe}(\mathrm{III})$ oxide reduction could play a major role in suppressing methanogenesis in freshwater environments. This applies to both in surface sediment ${ }^{[34]}$ and in the rhizosphere of aquatic plants ${ }^{[35]}$ where oxygen input from plant roots derives a dynamic Fe redox cycle. Oxygen from the rice tops is conducted to rice roots via arenchyma or air-conducting channels in the plant tissue of aquatic plant. ${ }^{[2]}$ In addition to Fe redox, C metabolism in wetland sediments is also affected by other terminal electronaccepting reactions involving oxygen, nitrate, manganese and sulfate reduction. ${ }^{[36-38]}$

Roden and Wetzel ${ }^{[39]}$ studied freshwater wetland sediments and demonstrated a direct correlation between first-order $\mathrm{Fe}(\mathrm{III})$ oxide reduction rate constants and initial rates of organic $\mathrm{C}$ mineralization (amount of carbon dioxide and methane accumulated). The results provide empirical support for existing approaches to modeling organic matter decay-dependent Fe(III) oxide reduction kinetics in sediments. 
Simulation of $\mathrm{Fe}(\mathrm{III})$ oxide reduction in freshwater wetland sediment where amorphous $\mathrm{Fe}(\mathrm{III})$ oxide is the dominant form of $\mathrm{Fe}(\mathrm{III})$ available for microbial reduction can be conducted with the simple organic matter decay-dependent first-order rate model described by the authors. $^{[39]}$

In a recent study of 15 West African rice soils, Sahrawat and $\mathrm{Narteh}^{[40]}$ demonstrated that the concentration of macro- and micronutrients released under submerged conditions in these soils, measured by EC of soil solution, was significantly correlated to organic $\mathrm{C}$ and reducible Fe extracted by EDTA. These results indicate the importance of reducible $\mathrm{Fe}$ on the release of plant nutrients in soil solution of submerged rice soils that are rich in $\mathrm{Fe}$.

\section{REDUCIBLE IRON AND AMMONIUM PRODUCTION}

Ammonium fixation and release in submerged tropical rice soils is affected by reducible $\mathrm{Fe}$ and it has been suggested that ammonium dynamics in submerged soils is greatly influenced by Fe redox reactions. ${ }^{[41]}$ During submergence, ammonium fixed under nonsubmerged conditions by amorphous $\mathrm{Fe}$, is released following the reduction of $\mathrm{Fe}(\mathrm{III})$ to $\mathrm{Fe}$ (II). Under reduced conditions in soils and sediments, the sorbed ammonium is released by both $\mathrm{Fe}$ (III) reduction to $\mathrm{Fe}(\mathrm{II})$ and exchange with $\mathrm{Fe}(\mathrm{II}){ }^{[15,41,42]}$

A study of $\mathrm{N}$ mineralization in diverse West African rice soils, showed that although extractable $\mathrm{Fe}$ was not directly correlated to ammonium produced under waterlogged condition, its inclusion in the multiple regression analysis improved the prediction of ammonium production. ${ }^{[13]}$

In a recent study with 15 diverse West African soils, Sahrawat and $\mathrm{Narteh}^{[43]}$ showed that mineralizable $\mathrm{N}$ or ammonium production under anaerobic condition was significantly correlated to organic $\mathrm{C}(r=0.79$, $n=15)$ and $\mathrm{Fe}$ extracted by $\operatorname{EDTA}(r=0.86)$ or ammonium oxalate $(r=0.75)$. Ammonium released in soil solution of the submerged soils was also significantly correlated to EDTA extractable $\mathrm{Fe}(r=0.60)$ or ammonium oxalate-extractable $\mathrm{Fe}(r=0.60)$ although the correlation coefficients were lower than those with the mineralizable N. Multiple regression analysis of the data showed that ammonium production in soils or ammonium released in soil solution can be predicted from organic C and EDTA or ammonium oxalate extractable Fe.

Several authors have suggested that EDTA and ammonium oxalate solutions extract fractions of amorphous Fe that are easily reducible and 
thus can be utilized as the measure of the activity of poorly crystalline $\mathrm{Fe}(\mathrm{III})$ oxides in soils. ${ }^{[44,45]}$ Moreover, research has shown that the amorphous $\mathrm{Fe}$ fractions contribute to $\mathrm{Fe}(\mathrm{II})$ production in reduced (Eh $150-180 \mathrm{mV}$ ) soils and sediments. The intensity of $\mathrm{Fe}(\mathrm{II})$ production increases with a decrease in the crystallinity of the pedogenic Fe(III) oxides and hydroxides and with an increase in the easily mineralizable organic substances. ${ }^{[30,46-49]}$.

Based on research conducted with West African rice soils, Sahrawat and $\mathrm{Narteh}^{[50]}$ concluded that a chemical index based on organic matter and reducible $\mathrm{Fe}$ contents can be used for predicting ammonium production in submerged soils. Multiple regression equations relating organic $\mathrm{C}$ and reducible $\mathrm{Fe}$ (extracted by EDTA or ammonium oxalate) to ammonium $\mathrm{N}$ released can be used for determining the $\mathrm{N}$ mineralization potential of wetland soils.

The relationships of organic $\mathrm{C}$ and reducible $\mathrm{Fe}$ with ammonium produced in 15 West African soils were represented by the following regression equations:

$$
\begin{aligned}
& \text { Mineralizable } \mathrm{N}\left(\mathrm{mg} \mathrm{kg}^{-1} \text { soil }\right) \\
& =16.4+1.320 \text { Organic } \mathrm{C}\left(\mathrm{g} \mathrm{kg}^{-1}\right) \\
& \quad+0.0369 \mathrm{EDTA}-\mathrm{Fe}(\mathrm{mg} \mathrm{kg}-1) ; \quad R^{2}=0.85 \\
& \text { Mineralizable } \mathrm{N}\left(\mathrm{mg} \mathrm{kg}^{-1} \text { soil }\right) \\
& =11.14+1.805 \text { Organic } \mathrm{C}\left(\mathrm{g} \mathrm{kg}^{-1}\right) \\
& \quad+0.00469 \text { Ammonium oxalate-Fe }\left(\mathrm{mg} \mathrm{kg}^{-1}\right) ; \quad R^{2}=0.81
\end{aligned}
$$

It was found that soils high in both organic $\mathrm{C}$ and reducible $\mathrm{Fe}$ were

\begin{tabular}{|c|c|c|c|c|}
\hline \multirow{2}{*}{$\begin{array}{l}\text { Min-N } \\
\mathrm{mg} \mathrm{kg}^{-1} \text { soil }\end{array}$} & \multirow[b]{2}{*}{ No. of soils } & \multirow{2}{*}{$\begin{array}{l}\text { Organic C } \\
\mathrm{g} \mathrm{kg}^{-1} \text { soil }\end{array}$} & EDTA-Fe & Amox-Fe \\
\hline & & & \multicolumn{2}{|c|}{$\mathrm{mg} \mathrm{kg}^{-1}$ soil } \\
\hline $86-166$ & 4 & $23.0-46.0$ & $150-2200$ & $1875-11412$ \\
\hline $55-77$ & 5 & $9.2-23.2$ & $325-800$ & $1100-6750$ \\
\hline $21-50$ & 6 & $7.4-15.6$ & $125-600$ & $925-3562$ \\
\hline
\end{tabular}
high in mineralizable $\mathrm{N}$. On the other hand, soils low in organic $\mathrm{C}$ or reducible Fe had relatively lower contents of mineralizable $\mathrm{N}$ (Table 3).

Table 3. Distribution of 15 West African rice soils according to mineralizable $\mathrm{N}$ (Min-N) released under anaerobic incubation and associated organic $\mathrm{C}$ and EDTA (EDTA-Fe) or ammonium oxalate extractable Fe (Amox-Fe) contents. ${ }^{[50]}$ 
These results are supported by highly significant correlations between mineralizable $\mathrm{N}$ and organic $\mathrm{C}$ and reducible $\mathrm{Fe}$ extracted by EDTA or ammonium oxalate. ${ }^{[43]}$

\section{PERSPECTIVES}

The research discussed in this article indicates those $\mathrm{Fe}$ redox reactions, controlled by reducible $\mathrm{Fe}$, influence ammonium production or $\mathrm{N}$ mineralization in submerged soils and sediments. Reducible $\mathrm{Fe}$ along with organic matter controls the $\mathrm{N}$ mineralization process in submerged rice soils where $\mathrm{Fe}$ is abundant. It appears that the availability of electron acceptors such as $\mathrm{Fe}(\mathrm{III})$ oxides might greatly influence ammonium production in reduced soils. However, since $\mathrm{Fe}$ is present in high amounts especially in tropical rice soils, it exerts a dominant role not only in soil reduction but also in the release of ammonium in submerged soils and sediments. In the absence of oxygen, ferric Fe serves as an electron acceptor and affects organic matter oxidation and ammonium production, ${ }^{[16,51]}$ although the mechanisms involved, especially in ammonium production are not fully understood.

A better understanding of the involvement of reducible $\mathrm{Fe}$ in $\mathrm{N}$ mineralization in submerged soils and sediments will lead to improved methods for assessing their $\mathrm{N}$ supplying capacity. There is an obvious need to conduct further research in understanding the role of Fe redox reactions in influencing $\mathrm{N}$ supply and cycling in submerged soils and sediments. Because $\mathrm{N}$ supply and cycling has a major influence in controlling the wetlands' role in controlling productivity, regulating environmental quality and determining the sustainability of the wetland ecosystems. Obviously, the research in this area is of scientific, environmental and agricultural interest. It is hoped this article will stimulate further research in this area.

\section{REFERENCES}

1. IRRI. Rice Almanac, 2nd Ed.; International Rice Research Institute: Manila, Philippines, 1997.

2. Ponnamperuma, F.N. The chemistry of submerged soils. Adv. Agron. 1972, 24, 29-96.

3. Ponnamperuma, F.N. Effects of flooding on soils. In Flooding and Plant Growth; Kozlowski, T., Ed.; Academic Press: New York, 1984; 9-45. 
4. van Breemen, N. Effects of seasonal redox processes involving iron on the chemistry of periodically reduced soils. In Iron in Soils and Clay Minerals; Stucki, J.W., Goodman, B.A., Schwertmann, U., Eds.; D. Reidel: Dordrecht, The Netherlands, 1988; 797-809.

5. Sahrawat, K.L. Flooding soil: a great equalizer of diversity in soil chemical fertility. Oryza 1998, 35, 300-305.

6. Narteh, L.T.; Sahrawat, K.L. Influence of flooding on electrochemical and chemical properties of West African soils. Geoderma 1999, 87, 179-207.

7. Ponnamperuma, F.N. Dynamic aspects of flooded soils and the nutrition of the rice plant. In The Mineral Nutrition of the Rice Plant; International Rice Research Institute, Ed.; Johns Hopkins University Press: Baltimore, MD, 1965; 295-382.

8. Moormann, F.R.; van Breemen, N. Rice: Soil, Water, Land; International Rice Research Institute: Manila, Philippines, 1978.

9. Patrick, W.H., Jr.; Reddy, C.N. Chemical changes in rice soil. Soil and Rice; International Rice Research Institute: Manila, Philippines, 1978; 361-379.

10. Sahrawat, K.L. Nitrogen availability indexes for submerged rice soils. Adv. Agron. 1983, 36, 415-451.

11. Sahrawat, K.L. Mineralization of soil organic nitrogen under waterlogged conditions in relation to other properties of tropical rice soils. Australian J. Soil Res. 1983, 21, 133-138.

12. Ando, H.; Arogones, R.C.; Wada, G. Mineralization pattern of soil organic nitrogen of several soils in the tropics. Soil Sci. Plant Nutr. 1992, 38, 227-234.

13. Narteh, L.T.; Sahrawat, K.L. Potentially mineralizable nitrogen in West African lowland rice soils. Geoderma 1997, 79, 145-154.

14. Narteh, L.T.; Sahrawat, K.L. Ammonium in solution of flooded West African soils. Geoderma 2000, 95, 205-214.

15. Davison, W. Iron and manganese in lakes. Earth Sci. Rev. 1993, 34, 119-163.

16. Lovley, D.R. Microbial reduction of iron, manganese, and other metals. Adv. Agron. 1995, 54, 175-231.

17. Gao, S.; Tanji, K.K.; Scardaci, S.C.; Chow, A.T. Comparison of redox indicators in a paddy soil during rice-growing season. Soil Sci. Soc. Am. J. 2002, 66, 805-817.

18. Schwarzenbach, R.P.; Gschwend, P.M.; Imboden, D.M. Environmental Organic Chemistry; John Wiley and Sons: New York, 1993.

19. James, B.R. Redox phenomena. In Encyclopedia of Soil Science; Lal, R., Ed.; Marcel Dekker, Inc.: New York, 2002; 1098-1100. 
20. Stucki, J.W. Structural iron in smectite. In Iron in Soils and Clay Minerals; Stucki, J.W., Goodman, B.A., Schwertmann, U., Eds.; D. Reidel: Dordrecht, The Netherlands, 1988; 625-675.

21. Favre, F.; Tessier, S.; Abdelmoula, M.; Genin, J.M.; Gates, W.P.; Boivin, P. Iron reduction and changes in cation exchange capacity in intermittently waterlogged soil. European J. Soil Sci. 2002, 53, 175-183.

22. Sherman, G.D.; Matsusaka, H. The role of amorphous fraction in the properties of tropical soils. Agrochimica 1964, 8, 146-163.

23. Deshpande, T.L.; Greenland, D.J.; Quirk, J.P. Role of iron oxides in the bonding of soil particles. Nature 1964, 201, 107-108.

24. Shanmunganathan, R.T.; Oades, J.M. Modification of soil properties by manipulating the net surface charge on colloids through addition of Fe(III) polycations. J. Soil Sci. 1982, 33, 451-465.

25. Savant, N.K.; McClellen, G.H. Do iron oxide system influence soil properties and $\mathrm{N}$ transformation in soils under wetland ricecropping systems? Commun. Soil Sci. Plant Anal. 1987, 18, 83-113.

26. Berner, R.A. A new geochemical classification of sedimentary environments. J. Sediment. Petrol. 1981, 51, 359-365.

27. Bartlett, R.J. Characterizing soil redox behavior. In Soil Physical Chemistry, 2nd Ed.; Sparks, D.L., Ed.; CRC Press: Boca Raton, FL, 1999; 371-397.

28. Patrick, W.H., Jr. Apparatus for controlling the oxidation-reduction potential of waterlogged soils. Nature 1966, 212, 1278-1279.

29. Sparks, D.L. Kinetics of Soil Chemical Processes; Academic Press: New York, 1989.

30. Schwertmann, U. Inhibitory effect of soil organic matter on the crystallization of amorphous ferric hydroxide. Nature 1966, 212, 645-646.

31. Widdel, F.; Schnell, S.; Heising, S.; Ehreneich, A.; Assmus, B.; Schink, B. Ferrous iron oxidation by anoxygenic phototrophic bacteria. Nature 1993, 362, 834-835.

32. Roden, E.E.; Wetzel, R.G. Organic carbon oxidation and suppression of methane production by microbial Fe(III) oxide reduction in vegetated and unvegetated freshwater wetland sediments. Limonol. Oceanogr. 1996, 41, 1733-1748.

33. Hines, M.E.; Faganeli, J.; Planinc, R. Sedimentary anaerobic microbial biogeochemistry in the Gulf of Trieste, Northern Adriatic Sea: influences of bottom water oxygen depletion. Biogeochemistry 1997, 39, 65-86. 
34. Achtnich, C.; Bak, E.; Conrad, R. Competition for electron donors among nitrate reducers, ferric iron reducers, sulfate reducers, and methanogens in anoxic paddy soil. Biol. Fertil. Soils. 1995, 19, 65-72.

35. Frenzel, P.; Bosse, U.; Jansen, P.H. Rice roots and methanogenesis in a paddy soil: Ferric iron as an alternative electron acceptor in the rooted soil. Soil Biol. Biochem. 1999, 31, 421-430.

36. Wesrtrich, J.T.; Berner, R.A. The role of sedimentary organic matter in bacterial sulfate reduction: the $\mathrm{G}$ model tested. Limonol. Oceanogr. 1984, 29, 236-249.

37. Lovley, D.R.; Phillips, E.J.P. Organic matter mineralization with reduction of ferric iron in anaerobic sediments. Appl. Environ. Microbiol. 1986, 51, 683-689.

38. Canfield, D.E.; Thamdrup, B.; Hansen, J.W. The anaerobic degradation of organic matter in Danish coastal sediments: iron reduction, manganese reduction, and sulfate reduction. Geochim. Cosmochim. Acta 1993, 57, 3867-3883.

39. Roden, E.E.; Wetzel, R.G. Kinetics of microbial Fe(III) oxide reduction in freshwater sediments. Limnol. Oceanogr. 2002, 47, 198-211.

40. Sahrawat, K.L.; Narteh, L.T. A fertility index for submerged rice soils. Commun. Soil Sci. Plant Anal. 2002, 33, 229-236.

41. Sahrawat, K.L. Ammonium fixation in some tropical rice soils. Commun. Soil Sci. Plant Anal. 1979, 10, 1015-1023.

42. Smolders, A.J.P.; Lamers, L.P.M.; Moonen, M.; Zwaga, K.; Roelfs, J.G.M. Controlling phosphate release from phosphate-enriched sediments by adding various iron compounds. Biogeochemistry 2001, 54, 219-228.

43. Sahrawat, K.L.; Narteh, L.T. Organic matter and reducible iron control of ammonium production in submerged soils. Commun. Soil Sci. Plant Anal. 2001, 32, 1543-1550.

44. Borggaard, O.K. Extraction of amorphous iron oxides by EDTA from a Danish sandy loam. J. Soil Sci. 1979, 30, 727-734.

45. Schwertmann, U. Use of oxalate for iron extraction from soils. Canadian J. Soil Sci. 1973, 53, 244-246.

46. Patrick, W.H., Jr.; Gotoh, S.; Williams, B.G. Strengite dissolution in flooded soils and sediments. Science 1973, 179, 564-565.

47. Munch, J.C.; Ottow, J.C.W. Preferential reduction of amorphous to crystalline iron oxides by bacterial activity. Soil Sci. 1980, 129, 15-21. 
48. Wahid, P.A.; Kamalam, N.V. Reductive dissolution of crystalline and amorphous $\mathrm{Fe}(\mathrm{III})$ oxides by microorganisms in submerged soil. Biol. Fertil. Soils. 1993, 15, 144-148.

49. Olaleye, A.O.; Ogunkunle, A.O.; Sahrawat, K.L. Forms and pedogenic distribution of extractable iron in selected wetland soils in Nigeria. Commun. Soil Sci. Plant Anal. 2000, 31, 923-941.

50. Sahrawat, K.L.; Narteh, L.T. A chemical index for predicting ammonium production in submerged rice soils. Commun. Soil Sci. Plant Anal. 2003, 34, 1013-1021.

51. Sahrawat, K.L. Reducible iron affects organic matter oxidation and ammonium production in submerged soils and sediments. Current Sci. 2002, 83, 1434-1435. 


\section{Request Permission or Order Reprints Instantly!}

Interested in copying and sharing this article? In most cases, U.S. Copyright Law requires that you get permission from the article's rightsholder before using copyrighted content.

All information and materials found in this article, including but not limited to text, trademarks, patents, logos, graphics and images (the "Materials"), are the copyrighted works and other forms of intellectual property of Marcel Dekker, Inc., or its licensors. All rights not expressly granted are reserved.

Get permission to lawfully reproduce and distribute the Materials or order reprints quickly and painlessly. Simply click on the "Request Permission/ Order Reprints" link below and follow the instructions. Visit the U.S. Copyright Office for information on Fair Use limitations of U.S. copyright law. Please refer to The Association of American Publishers' (AAP) website for guidelines on Fair Use in the Classroom.

The Materials are for your personal use only and cannot be reformatted, reposted, resold or distributed by electronic means or otherwise without permission from Marcel Dekker, Inc. Marcel Dekker, Inc. grants you the limited right to display the Materials only on your personal computer or personal wireless device, and to copy and download single copies of such Materials provided that any copyright, trademark or other notice appearing on such Materials is also retained by, displayed, copied or downloaded as part of the Materials and is not removed or obscured, and provided you do not edit, modify, alter or enhance the Materials. Please refer to our Website User Agreement for more details.

\section{Request Permission/Order Reprints}

Reprints of this article can also be ordered at http://www.dekker.com/servlet/product/DOI/101081CSS120029721 
Copyright of Communications in Soil Science \& Plant Analysis is the property of Marcel Dekker Inc. and its content may not be copied or emailed to multiple sites or posted to a listserv without the copyright holder's express written permission. However, users may print, download, or email articles for individual use. 
Copyright of Communications in Soil Science \& Plant Analysis is the property of Taylor \& Francis Ltd and its content may not be copied or emailed to multiple sites or posted to a listserv without the copyright holder's express written permission. However, users may print, download, or email articles for individual use. 